\title{
What's Wrong with the IMF? What Would be Better?
}

\author{
By：Allan H. Meltzer
}

\section{Prepared for:}

Asia: An Analysis of Financial Crisis

Federal Reserve Bank of Chicago

October 8-10, 1998 
September, 1998

\section{WHAT'S WRONG WITH THE IMF? WHAT WOULD BE BETTER? By Allan H. Meltzer* \\ The Allan H. Meltzer Professor of Political Economy, Carnegie Mellon University and Visiting Scholar, American Enterprise Institute}

The International Monetary Fund (IMF) and the World Bank were created in 1944 reflecting the experience of the 1920s and 1930s. The Fund's tasks were to adjust current account imbalances and manage the exchange rate system. The Bank's main tasks were to lend for the reconstruction of Europe and eliminate the alleged bias against lending to developing countries.

Whatever may have been true in the 1940s, the international financial system has found other means of solving the problems that the Fund and the Bank were supposed to solve. Changes in exchange rates are now one common means of adjusting current account imbalances. Leading countries including the United States, Japan, Britain and the European Union allow their currencies to float. Within Western Europe there will soon be a common currency with a single central bank in place of fixed but adjustable exchange rates.

Many of the problems or international financial crises of recent years arose because there is too much lending, especially short-term lending, to developing countries, not too little. Recent history gives good support to the proposition that,

\footnotetext{
* I am grateful to Bennett McCallum and Charles Calomiris for helpful discussions.
} 
if a country adopts market-oriented policies of privatization and deregulation, opens its trade to competition in foreign markets and by foreigners in domestic markets, and carefully controls its budget, foreign lenders and investors are willing to finance development.

Yet, the international financial system is crisis-prone. Latin America in the 1980s, Mexico in the 1990s, and Asia and Russia now are well-known examples of deep, pervasive financial crises that have been costly to the public in the countries with financial problems, their trading partners, and, often, much the rest of the world. The past fifteen years have seen 90 serious banking crises, most of them followed by deep recessions. More than 20 of these crises produced direct losses to the developing country exceeding $10 \%$ of its GDP. In half of these cases, including several Asian countries now, losses exceed 25\% of GDP. Caprio and Klingabiel (1996, 1997); Calomiris (1998). These losses, relative to GDP, are far larger than the cost of the U.S. saving and loan problem to U.S. taxpayers.

The frequency and severity of recent international financial problems in a period of growth, economic progress, and low inflation should raise a series of questions. Why is there so much financial fragility? Is the current set of international institutions appropriate for current conditions? Have international financial arrangements and institutions adapted appropriately to the changes in the world economy? Is it time to agree upon new arrangements? What set of international financial arrangements will serve the world well for the next decades?

I do not pretend to have complete answers to all of these questions. I believe they are questions that economists and policymakers must ask and try to answer. This paper attempts to start that discussion. After pointing to what I believe are some of the failures of current arrangements, and their lack of fit with current problems, I propose some changes. I concentrate on the IMF, although there is now substantial convergence in the activities of the Bank and the Fund. I omit 
discussion of policy errors, for example in Asia in 1997. All policymakers err at times. The important issue, I believe, is not judgmental errors but structural flaws that support and encourage financial fragility.

\section{Origins and Rationale for the Fund and the Bank}

Planning for postwar international monetary cooperation began before the United States entered the war. The lend-lease agreement, under which Britain and others obtained military supplies and equipment on "credit", provided that the United States could waive postwar repayment if the British agreed to eliminate trade "discrimination." The term was not further defined, but the objective it expressed included elimination of the prewar system of imperial preference that bound its empire to Britain and favored British exports to its colonies.

As negotiations of postwar arrangements proceeded, trade issues faded into the background, and financial issues moved to center stage. By September 1941, Keynes had developed a proposal for an international currency union as part of the British contribution to discussion of postwar arrangements. With minor adjustments, Keynes's proposal became the British government proposal in April 1943, when formal bilateral discussions began. Meltzer (1988, pp. 236-37).

Keynes visited the United States in the fall of 1941 and may have discussed his plan informally. In December, a week after the United States entered World War II, Secretary Morgenthau asked Harry Dexter White to "prepare a memorandum on the establishment of an inter-Allied stabilization fund" as the basis for postwar international monetary arrangement. Blum (1967, v. 3, pp. 22829). ${ }^{1}$ Morgenthau's diary suggests that he had a vague idea about expanding the 1936 Tripartite Pact to avoid competitive devaluations.

\footnotetext{
${ }^{1}$ White was Director of Monetary Research and later Assistant Secretary of the Treasury. The U.S. proposal that became the basis of the International Monetary Fund is often referred to as the White Plan. Keynes's plan called for
} 
Keynes (1923) developed the basic analytic problem. Each country acting alone can achieve either stable prices or a fixed exchange rate but not both. To achieve both there must be international cooperation or agreement. The classical gold standard was one such agreement. Keynes (and others) had recognized earlier that the gold standard required deficit countries to bear the cost of adjustment, required pro-cyclical monetary policies, and was inflexible and costly for a country with downward wage rigidity. Like White, and many others, he considered the inflexibility of the gold standard, the distribution of gold, and the monetary policies of the surplus countries, mainly France and the United States, as leading causes of the great depression. The aim was to avoid a return to the classical gold standard while retaining enough of its features to solve the coordination problem while making the arrangement acceptable to prospective surplus and deficit countries.

Both Keynes's and White's plans and the Bretton Woods agreement imposed costs on surplus countries that would neither expand imports nor lend to deficit countries. The justification was elimination of an externality. By forcing adjustment on surplus countries, deficit countries would be spared higher interest rates and contraction. This would benefit surplus countries and others, since their exports and incomes would be maintained. If the surplus countries could be made to lend to the deficit countries, fluctuations in economic activity would be damped. Both surplus and deficit countries would gain. Of course, this could work only if the imbalance was temporary. Persistent imbalances required a change in exchange rates, with the consent of the IMF.

Both Keynes and White limited their proposals for the IMF to the financing of current account deficits. To the extent that financing of capital flows was

a clearing union to adjust current account balances of debtors and creditors. White envisaged a permanent fund that could lend to debtor countries. 
discussed, it was the proposed Bank for Reconstruction and Development (later the World Bank) that would be responsible. White explained privately why the U.S. favored an international bank.

"Many of the loans will be risky and there will be some losses. This is one of the reasons why we insisted that the Bank be an international bank rather than to take the risks ourselves. We felt that the benefits would be worldwide and that other countries should be at risk." H.D. White to the Board of Governors and Reserve Bank Presidents, Board Minutes (March 2, 1945, p. 17)

There were two reasons for the proposed bank. One is risk sharing, a reason that continues to be used. This is a distributive, not an efficiency argument. The second is the benefit to the world economy. This claim reflected the belief that economic development was hindered by risk averse lenders who restricted the supply of capital and charged premium rates. The supply of capital to developing countries was believed to be sub-optimal. The proposed bank would remove the capital market restriction.

Although the argument was not developed more carefully, it was widely accepted. The experience of the 1930s, when there were sizeable defaults by developing countries, was taken as evidence that lenders would be restrictive in the future.

The international system did not evolve as planned. Experience showed that many of the beliefs and conjectures on which it was based proved to be wrong. The United States did not return to its interwar policies. Instead of large, persistent surpluses, and high tariffs, it ran small surpluses or deficits on current account and worked to reduce tariffs globally. Loans and transfers added to the dollar claims held by foreigners. By 1951, the U.S. gold stock started a fall that, with a few brief interruptions, continued until the U.S. suspended gold sales in August 1971. 
During its early years, when the U.S. had its largest current surpluses, the Fund had a very modest role in the international payments system. The Marshall Plan redistributed part of the U.S. surplus, and the European Payments Union cleared payments imbalances for the inconvertible European currencies. Historians describe the early years as a period in which the status of the Fund and even its survival were in question. Presnell (1997, p. 229), James (1996)

The Fund became more active in the mid-1950s. For a few years, the new system functioned smoothly. Membership increased; more countries drew on the Fund's resources, and the amounts drawn increased. The Fund specialized in making relatively small, short-term loans. Since repayment was usually prompt, the Fund recycled its resources. James (1996)

This period was followed by a series of crises or disturbances affecting key currencies, first the pound, then the dollar. By 1968, the U.S. gold stock had fallen so far that a de facto restriction on gold convertibility was in place. The fixed but adjustable rate system limped through the next two years. In mid-1971, convertibility ended formally with the closing of the gold window.

If the original plan had been implemented, the IMF would have ceased to exist in 1973 when the fixed but adjustable rate system officially ended. The Bretton Woods system left capital account lending to the World Bank. The Fund no longer had a reason for being.

\section{Recent History}

In the 1970s and 1980s, the Fund took an important role in capital account lending to "recycle" the revenues of oil producing countries after the oil price rise. Its role as advisor to developing countries on macro-economic adjustment increased. This advice was tied to lending; the Fund made loans to ease the burden of adjustment to the structural and macro-economic reforms it advocated. 
Edwards (1989, p. 78) summarizes the results of an internal IMF study by Mohsin Khan of these policies and actions. "Khan found that Fund programs had a statistically nonsignificant effect on the balance of payments, a nonsignificant effect on inflation, a significant positive effect on the current account, and a significantly negative effect on output." In other words, the Fund's programs moved the current account toward balance by reducing output, income, and imports. The conditions for IMF assistance required countries to control inflation, but the condition was not met in many countries. IMF research found no significant effect of its programs on inflation. ${ }^{2}$

Beginning in the summer of 1982, the Fund greatly expanded lending to countries experiencing capital outflow. It continued to lend during the years of financial distress known as the "Latin American debt crisis." This was a major extension of its capital market program. The size of loans and the time to repayment increased. Many countries became permanently indebted to the Fund.

The Fund's main function in the 1980s was lending money to debtor countries to pay interest on their outstanding debts to the Fund and commercial banks. As part of these arrangements, commercial banks also increased their loans to indebted countries. Most of this was an accounting operation to avoid recognizing defaults. The result was that Latin American debt rose, the creditor banks were protected, and the debtor countries continued to suffer under a rising debt burden and falling per capita income.

IMF programs postponed recognition of losses by U.S. and other international banks at the expense of living standards in Latin America. By the end of the decade, as part of so-called Brady adjustments, banks accepted part of their

\footnotetext{
${ }^{2}$ I believe there is a likely reason for failures in some cases and success in others. Success requires support by domestic political leaders and local institutions. For an example in Mexico, see Calomiris (1998).
} 
losses, workout agreements were reached for the remaining debt, and growth resumed in Latin America.

Latin American loans were made under the IMF's conditional lending program under which governments agreed to follow stabilizing policies. As before, the problem was enforcement against sovereign governments. The IMF's main threats were to cancel the loan program or withhold payments. In a preview of what was to happen in Russia and Asia, the threats usually proved to be empty. The main reasons are of interest because they show some principal flaws in the system.

First, the IMF becomes committed to the "success" of the program. Cancellation is seen as a failure. Governments understand that the IMF is reluctant to withhold funds or cancel programs. Hence the threat loses force.

Second, IMF officials are judged partly on their contacts with high officials of borrowing governments. Critical reports by an IMF task force reduce the welcome the IMF team can expect on its next visit. The finance minister is "too busy". Failure to meet with principal officials is treated as a "failure," harmful to the IMF official's career. Borrowing governments recognize this power, so they are able to restrain criticism and prevent or delay information from reaching the IMF's top management. ${ }^{3}$

The Latin American program was a model for subsequent capital market programs. The next large financial crisis was in Mexico in 1994-95. Again, the IMF, with assistance from the U.S. Treasury, protected foreign banks and financial institutions by allowing them to avoid portfolio losses. Although many of the foreign commercial banks had made loans in 1994 at interest rates of $20 \%$ per annum or more, they were not required to bear the risk that they had undertaken.

\footnotetext{
${ }^{3}$ This partially explains why the IMF's management is often slow to recognize emerging problems. The two reasons also help to explain why the IMF tolerated corruption in Indonesia, Russia, and elsewhere.
} 
Instead the IMF loaned money to Mexico at below market interest rates. Again, the international bankers were spared, while the economy suffered a severe recession.

The IMF and the U.S. Treasury claim success in Mexico. A principal reason, I suspect, is that the loans by the IMF and the U.S. Treasury were repaid. Much of the repayment was effected by the Mexican government borrowing in capital markets at higher rates of interest, surely not an improvement from the standpoint of Mexican economic welfare.

The welfare losses to Mexicans were much larger than the increased interest payments. Chart 1 shows Mexico's per capita real GDP in U.S. dollars. The striking feature of the chart is that per capita income in 1997 was only slightly higher than in 1973. In a period of rising world real incomes, Mexican income was highly variable but stagnant. Meanwhile debt per capita rose by a factor of three or four so, after 25 years, with income unchanged on average, taxes for debt service were much larger and Mexican disposable income per capita was smaller.

\section{Insert Chart 1 here}

The IMF, the Bank, and the U.S. Treasury are not responsible for all of the problems that Mexico experienced. Oil price changes and mistaken policies of the Mexican government made large contributions. To the extent that IMF support contributed to the durability of mistaken policies and to the burden of the debt, the IMF must bear some responsibility. Mexico is far from the success that IMF and U.S. Treasury officials proclaim. The IMF did not foresee the Mexican crisis partly because the Mexican government did not provide information, partly because of the incentives within the IMF discussed above.

One promising feature of the Mexican program was a new departure on which better arrangements can be built. Mexico gave a lien against Mexican oil revenues to guarantee repayment of its U.S. government loan. Use of collateral to 
support borrowing is a helpful step, but it raises a question about why oil revenues could not have been used to guarantee private lending without subsidies from the IMF.

A bad feature of the Mexican program was its contribution to the belief that international banks had a safety net not available to investors in equities or purchasers of real assets in foreign countries. The message implicit in these actions was clear to bankers and investors. Between 1990 and 1996, capital flows to emerging markets rose from $\$ 60$ billion to $\$ 194$ billion. After 1995, with Mexican experience in mind, portfolio investment declined, but bank lending increased.

In the past twenty years, the IMF has introduced two new loan facilities. One is the Extended Structural Adjustment Facility (ESAF). The other is the Structural Transformation Facility (STF) to assist former members of the communist bloc, including Russia and states of the former Soviet Union. Both facilities extend the conditional lending procedures in new directions without correcting the flaws.

ESAF offers medium-term loans at an interest rate of $0.5 \%$ with repayments up to 10 years. The borrower agrees to make structural adjustments such as fiscal reform, privatization, and trade liberalization. "A recent IMF-World Bank study concludes that the results of ESAF loans have been largely negative in terms of reducing budget deficits and inflation and mixed in terms of producing external viability and promoting per capita growth." Quoted in Mikesell (1998, p. 31)

The STF has contributed to transformation in several former communist countries. The bulk of its funds---and other IMF-World Bank loans---have gone to Russia where policy mistakes, misjudgments, and corruption have prevented successful transformation. When oil and commodity prices fell in 1998, lenders began to question Russia's ability to service its large outstanding debt. 
A principal policy mistake in Russia is neglect of the necessary conditions for transformation to a capitalist economy. The conditions include structural reforms that increase transparency of business and government reports and statistics, establish private property, a commercial code, accounting standards, and enforcement through the rule of law. Some commercial and industrial property has been privatized, often in deplorable ways, but $90 \%$ of agricultural land remained under state or collective controls in 1997. And Federal law does not permit the sale of agricultural land. In contrast, China began its more successful reform program by introducing long-term leases that had many features of private ownership of agricultural land.

The above structural reforms, if adopted, would have provided a Hayekian infrastructure. A structure of this kind introduces incentives that direct resources to efficient uses. Capitalism is more than trade at market prices. Successful capitalism is a set of institutions that provides incentives compatible with economic development, efficient use of resources and enforcement of contracts. These features of successful capitalist countries are missing in Russia and many countries of the former Soviet Union. The IMF has shown little interest in encouraging these reforms.

Corruption and mismanagement are widespread in Russia. Published estimates in 1997 suggested that capital flight was about \$2 billion per month with a total of $\$ 150$ billion from Russia since the breakup of the USSR Jenkins (1998, quoting Global Finance). A report by the Director of the Chamber of Accounts of the Russian Federation gives some specific examples. ${ }^{4}$ Sokolov (1998)

(1) Parliament appropriated $\$ 150$ million to build planes for sale to India. An audit showed that none of the funding reached the enterprise.

\footnotetext{
${ }^{4}$ The Chamber of Accounts is the Russian equivalent of the General Accounting Office. Venyamin Sokolov is a director of the chamber.
} 
(2) Parliament appropriated funds to aid Chechnya after the war ended. The total bill was $\$ 3$ billion. The audit found documentation for $\$ 2$ billion, less than $\$ 150$ million reached Chechnya. No record of the remainder was found.

(3) \$30 million of a World Bank loan was allocated to compensate victims of bank frauds and pyramid schemes. Audits showed that after several years, not a single victim had received payment.

(4) The government issued debt to finance a large fraction of its payments. Forty-five percent of state revenues in 1998 went to pay interest on the debt. "This means no money is left to pay workers or to support education, public health" or other government services. (ibid)

These criticisms were made before recent crises drove interest rates above a $100 \%$ annual rate. The IMF did not publicly condemn these improper and corrupt practices. We now know that the IMF was aware of the problems of inadequate accountability and corruption. It failed to enforce the conditions of its loans and the most elementary standards of accountability and performance.

IMF, U.S. and German government policies encouraged banks and financial institutions to believe that a Russian default on its debt would be avoided. IMF and U.S. actions had prevented lenders from taking losses in Mexico. If Mexico was critical to the stability of the United States, the reasoning went, surely Russia was more critical. On this reasoning, interest rates of $40 \%, 50 \%$ or $100 \%$ seemed to be a gift to international lenders--default premiums without comparable default risk.

Moral hazard arises when the private risk to the lender is less than the risk borne by society. This was clearly the case, ex ante and ex post in Mexico and in Asia. Banks and other lenders did not experience the large losses borne by 
ordinary citizens and owners of equity and real assets. Ex ante, banks and

financial institutions that made loans to Russia believed that they would be spared losses also. The $\$ 22$ billion loan promised by the IMF, World Bank and others in July seemed to confirm this view for a time. ${ }^{5}$ Inability of the Russian government to fulfill its commitments soon raised doubts, followed by capital outflow.

Moral hazard lending to Russia, encouraged by the bailout of foreign lenders to Mexico, permitted Russia to finance large, unbalanced budgets by borrowing externally. The result is a much larger financial problem for international lenders and possibly for economies in several countries. The IMF continued lending despite the Russian governments failure to meet the loan conditions. The IMF continued to lend when the Russian government "reduced its deficits" by not paying soldiers, miners, and others. Again, the IMF was committed to "success." The government understood that, so "conditionality" failed.

The IMF's mistake was to establish the STF and undertake structural reform. It had no prior experience and no special competence. The lessons it had learned, mainly in Latin America, concerned macroeconomic adjustment of market economies. It was slow to recognize that structural transformation involved the development of a Hayekian infrastructure. And it refused to learn a main lesson of its own past experience--sovereign governments cannot be compelled to implement programs that they do not favor. Policy changes will not be implemented unless they are supported by local political institutions and their leaders. ${ }^{6}$

\footnotetext{
${ }^{5}$ IMF promised $\$ 11.2$ billion in 1998 and $\$ 2.6$ additional in 1999 . This lending was an addition to $\$ 1.3$ billion committed earlier. The World Bank promised $\$ 6$ billion over the two years. Japan committed $\$ 1.5$ billion. The U.S. did not contribute this time. The proposal called for tax increases in Russia. The Russian government proposed a sales tax, despite estimates that more than $50 \%$ of Russian exchanges are barter exchanges. The government also planned to exchange up to $\$ 45$ billion of short-term ruble debt for longer-term dollar denominated debt.

${ }^{6}$ Cavallo (1998) draws the same conclusion from his experience as Argentina's finance minister. "If this [committed local leaders] doesn't exist, the IMF should stay out rather than attempt to force a government to implement a program it doesn't believe in." (ibid., p. 1) Cavallo argues that the IMF's main role should be to audit the programs developed domestically and, by improving some, help reforming countries to borrow in the capital markets. He adds that in 1995 he felt compelled to accept advice he considered incorrect to get IMF approval so that bankers would resume lending.
} 


\section{IMF Errors and Responses}

The IMF had more success in the 1960s when it limited its efforts to helping countries with current account deficits. As its scope expanded, its record became ambiguous or worse. In this section, I will comment on three errors or problems: (1) undertaking structural transformation lending and advice in Russia, (2) moral hazard, and (3) the ambiguous effects of IMF (and Bank) lending. These errors, and the IMF's responses, lead to recommendations for reform.

There was no previous experience on which to base transformation policies in Russia. Primarily for political and military reasons, there was intense interest in Europe and the U.S. to transform Russia into a more democratic, market economy. The G-7 governments either were unwilling, or believed they were unable, to obtain funding for the transformation from their parliaments. The IMF agreed to accept responsibility. In doing so, it moved far beyond its competence.

Even if its advice had been well-founded, the IMF had little scope for enforcing Russian commitments. Like most borrowers, Russian officials understood that the IMF and the G-7 had a stake in reform and transformation. The Fund could threaten to withhold payments. It did, on occasion, delay payments. As in many previous experiences, however, the Fund did not want the program to fail.

Governments in Russia (and other countries) understand that the Fund's commitment to "success" weakens its ability to enforce threats. The IMF was unwilling to call attention to widespread corruption, failure to implement reforms, and cynical maneuvers to reduce reported budget deficits by failing to pay civil servants, coal miners, soldiers, and others. ${ }^{7}$

\footnotetext{
${ }^{7}$ One may also question the rationale for some "reforms". In a country where fifty percent or more of all transactions are reported to be barter exchanges, increasing the sales tax is an odd reform to propose.
} 
Russia differed from other countries in many ways, but the IMF's failure in Russia was not unique. The IMF also tolerated corruption in Indonesia. In Korea, Indonesia, and elsewhere, it tolerated fragile financial systems used to subsidize projects favored by government officials or their political supporters. A main question about these and other failures is whether the IMF lending delayed reform both directly by lending and by encouraging private capital inflows. These additional resources may have contributed to reform, but they also permitted bad policies to continue.

No single answer can be given for all countries. There may be countries where IMF loans helped reform politicians to make changes that would have been delayed or avoided. It seems clear, however, that IMF lending, and the private capital flows that followed, permitted unbalanced budgets, fragile financial systems, government subsidies to specific programs through banking systems, and corruption to continue longer and at higher levels.

Much has been written about moral hazard in Asian lending. I want to distinguish two separate problems. First is the effect of IMF policies toward Mexico and Russia on private lenders. The second is the decision to delay reform knowing that IMF lending, at low interest rates, is available in a crisis.

IMF officials minimize the role of moral hazard in Asia. A typical statement is that no government pursues policies that lead to the loss of output, employment and living standards experienced by Mexico, Thailand, Indonesia, Korea, and others. Fischer (1998, p. 5) calls "far fetched" the idea that policymakers will take excessive risks because the IMF can help.

This defense shows little understanding of the way the financial problem develops. Ministers of Finance do not set out to generate a crisis. At each critical decision point, however, they often decide to allow an additional increase in shortterm foreign borrowing rather than adopt policies that would avoid the crisis. A 
common example from Mexico, Korea and others is the decision to offer exchange guarantees to foreign lenders who are reluctant to renew loans. The guarantees may sometimes be followed by stabilizing policies, but in many countries, they are not. Rather, they postpone and enlarge the subsequent crisis.

This behavior is understandable. The crisis is not a "sure thing." As always, there are risks both ways. A government that adopts restrictive policies early runs the risk that parliament will not approve, that the opposition will claim the policies were unnecessary, and that voters will support the opposition.

This behavior is not unique to developing countries, and it does not occur only in countries that borrow from the IMF. The U.S. government delayed responding to the saving and loan problem for many years. The arguments were similar at the time. Japan delays a solution to its banking problems. The finance minister who chooses delay may be proved right. Even if he is wrong, a crisis may not occur during his term of office. IMF loans, at subsidized rates, are available. ${ }^{8}$ A timely loan may require some retrenchment, but all countries that go to the IMF do not have a crisis.

It is sufficient for moral hazard that the existence of subsidized loans from the IMF modifies the finance minister's evaluation of the costs he faces. The very large increase in the number of countries experiencing large crises in recent years suggests that a change of this kind has occurred. Perhaps the severity of the crises in Indonesia, Thailand, Korea, and Russia will change future behavior. I believe that institutional reform is desirable even in this case.

A more problematic defense compares the IMF's rescue packages for international banks to the rescue of some of the passengers on the Titanic. ${ }^{9}$ The

\footnotetext{
${ }^{8}$ The IMF has recently raised its lending rates to Korea, a constructive step.

${ }^{9}$ This argument was used by Michael Mussa at the June Brookings Conference (and perhaps elsewhere.) It was repeated by First Deputy Managing Director Stanley Fisher at the American Enterprise Institute's World Forum in June. The author was present on both occasions.
} 
comparison is inapt. There is no important difference between individual and social losses when a ship like the Titanic sinks. There was no learning by other ships or their captains as a result of the rescue. In the Mexican and Asian crises, there are large differences between the losses borne by international banks and the losses to the Mexican, Thai, Indonesian, Korean and other populations. Bankers learned that the IMF and the U.S. Treasury would lend to reduce losses to large banks and financial institutions.

IMF and U.S. Treasury loans to Mexico permitted the Mexican government to honor most of the exchange guarantees on the dollar-guaranteed bonds called Tesobonos. By asking member governments subsequently for a large quota increase, the IMF furthered the belief that similar commitments by governments in Asia, Russia or elsewhere would be honored. If the IMF was not planning large future rescues of banks and lenders, why was a large increase in funding, about $\$ 80$ billion, needed?

The IMF is not responsible for all the errors that governments make. Nor is it responsible for all the errors made by lenders and borrowers. At issue is whether IMF lending increases the risks in the international financial system. By minimizing the moral hazard problem, the IMF avoids recognizing that it is part of the problem. Its behavior encourages too much short-term lending by financial institutions and too few losses on risky loans.

The third problem is that the effects of conditional lending are ambiguous. Lending may encourage reform, for example by reducing transition costs and strengthening the position of reform proponents. But, lending also may delay reform by permitting governments to continue inappropriate policies. The IMF lacks adequate mechanisms for enforcing desirable change and avoiding retrograde actions. 
IMF officials have not proposed effective programs for strengthening the international financial system. Some hint at the possibility of restricting short-term capital movements. Fischer $(1998$, p. 7) Other suggestions include improved supervision or more timely information.

One need not oppose the suggestions for improving information and supervision. They may be helpful, but they are insufficient. Studies from Benston (1973) to Berger et al. (1998) show that banking supervisors and regulators rarely foresee failures. With modern financial instruments, a banker can change portfolio risk as soon as the examiner leaves the bank. Moreover, there are better alternatives. Based on experience with large-scale failures and moral hazard, some countries have reduced their reliance on supervision and regulation. Recent practice in New Zealand, Chile, the United States and elsewhere now relies more on capital and market-based incentives to increase safety and soundness. ${ }^{10}$

\section{Suggestions for Reform}

The IMF was created to assist in adjustment of current account imbalances in a world with fixed exchange rate and widespread capital account restrictions. The World Bank was given responsibility for capital transfers on the presumption that government programs were needed to compensate for a sub-optimal volume of development lending.

The conditions under which these institutions were founded are no longer with us. It is time to consider the institutions and arrangements useful for current and expected future conditions. I believe there are structural flaws in the current system, in part because it developed as a response to specific problems and without attention to the longer-term effects of the changes that were made.

\footnotetext{
${ }^{10}$ Meltzer (1995) reviews a large literature on safety and soundness issues in developing countries.
} 
To encourage discussion of these issues, this section offers some tentative proposals to improve the functioning of the international financial system by increasing efficiency and reducing moral hazard. My aim is to open discussion of arrangements that maintain capital flows and international lending, while reducing the frequency and depth of financial panics and the losses to countries and their citizens. The proposed system seeks to reduce moral hazard and avoid both subsidies to lending and regulatory restrictions or taxes that prohibit types of lending. There are seven proposals. ${ }^{11}$

1. Increased reliance on fluctuating exchange rates. Many of the exchange rates may be "dirty floats", but I believe experience has shown that capital mobility, fixed exchange rates, price stability, and full employment are rarely compatible. Rogoff (1998) shows that, in recent years, few countries have been able to maintain a fixed exchange rate for six years or longer. Floating exchange rates shift costs to lenders who withdraw their capital and raise the price borrowers pay for large capital inflows. Plus, they reduce inflows and outflows.

2. Improved management of capital flows. Central banks can manage their exchange rate systems to maintain price or economic stability. If a capital inflow threatens stability, the central bank can (1) permit the exchange rate to appreciate, (2) sterilize the inflow by selling domestic securities, or (3) do some of each. Similarly, the central bank can offset capital outflow by allowing the exchange rate to depreciate or by buying domestic assets.

3. Increased reliance on competition in local banking markets. Many producers of goods or services diversify risk in their international operations by locating facilities in many countries. The Coca-Cola Company has expanded internationally since the 1930s. It prospered despite wars, inflation, and many local or regional crises. The company has learned to manage the risk inherent in

\footnotetext{
${ }^{11}$ Earlier versions are Meltzer (1998a) (1998b).
} 
an internationally diversified company and has provided a model that others have followed. Many countries do not permit banks to follow this model. They prevent international banks from competing in local markets. International banks are limited to making mainly dollar (yen or D-mark) loans to local banks. If international banks held portfolios of local assets and issued local currency liabilities, country risks would be part of a diversified international portfolio. Diversification would reduce the cost of bearing risk. Competition would work to improve local banking practices.

4. Increased size and diversification. Many countries are too small to achieve optimal diversification of financial assets. Loans to a few industries dominate portfolios of local banks. ${ }^{12}$ Sub-optimal diversification has been a principal cause of bank failures throughout U.S. history. Admission of foreign banks to local markets should be accompanied by rules for bank capital that prevent international banks from leaving in a crisis. There are different ways to sustain commitment to the country. All involve greater losses from withdrawing than from remaining, hence capital or asset holdings denominated in local currency.

5. Establish an international lender of last resort. More than a century ago, Bagehot (1873) explained that a financial system requires a lender of last resort to assist financial institutions in a liquidity crisis. Unlike the IMF and many country central banks, Bagehot distinguished between liquidity and solvency and provided rules that separated the two. He required the borrower to offer marketable assets as collateral for a loan, and he required the lender to charge a penalty rate on all such loans. The collateral requirement separates insolvent from illiquid banks. The penalty rate eliminates subsidies, reduces moral hazard and reduces reliance on the

\footnotetext{
${ }^{12}$ Close relationships between industrial conglomerates and banks in Asia add to this problem. The problem would arise in many Asian countries even if the relationships ended.
} 
lender. Most of the time the lender of last resort would be idle. Markets would function, and borrowers would offer collateral. This means that they would hold such collateral, or they could not get assistance.

6. Enforcement of the collateral requirement has stabilizing dynamic properties. Central banks could borrow from the international lender of last resort only on the presentation of internationally traded assets, so they would be induced to hold such assets. They would lend to domestically chartered banks, in the event of bank runs. The international lender of last resort would be barred by statute from making loans without receiving marketable collateral (at a price below last market price). A foreign government that wished to circumvent collateral requirements to assist a developing country would have to obtain an appropriation through its legislature.

7. Development lending would be done through the capital markets. Experience has shown that, if a country opens its markets, controls spending and budget deficits, reduces inflation, and deregulates and privatizes, capital comes. International financial institutions are no longer needed for development lending. A modest role for redistributive lending to reduce poverty would remain.

The combined effect of fluctuating exchange rates, diversified international banks, capital requirements, and a Bagehotian lender would reduce reliance on short-term capital flows and the crises that occur when several international lenders simultaneously fail to renew their loans. A Bagehotian lender of last resort reduces moral hazard.

At the organizational meeting of the IMF and World Bank, Keynes argued against locating these institutions in Washington. His concern was that they would be overly influenced by U.S. domestic politics and the pressures generated by domestic interest groups. It is not known whether such pressures would be 
dampened by locating the lender of last resort outside the U.S. I believe it is a subject worth more study.

Finally, what should be done about assistance to Russia? This is primarily a political question, and it should be treated as a political issue. Parliaments should be asked to appropriate transfers, perhaps in exchange for warheads and missiles, as was done in Ukraine. There is a possible collective benefit that has little relation to international development lending. Mixing the two was a mistake that is now apparent to all. 


\section{Bibliography}

Bagehot, Walter, (1873). Lombard Street. London: Scribners, Armstrong. Reprinted 1962 Homewood: Richard D. Irwin.

Benston, George J., (1973). Bank Examination. Bulletin of the Institute of

Finance. New York: Graduate School of Business Administration, New York University (May) entire issue.

Berger, Allen, Davies, Sally, and Flannery, Mark J., (1998). "Comparing Market and Supervising Assessments of Bank Performance: Who Knows What When? Board of Governors, Finance and Discussion Series, 1998-32.

Blum, John M., (1967). From the Morgenthau Diaries: Years of War. Boston: Houghton Mifflin.

Board Minutes, (1945). Board of Governors (unpublished).

Calomiris, Charles, (1998). "The IMF's Imprudent Role as Lender of Last Resort." Cato Journal, 17 (winter), pp. 275-94.

Cavallo, Domingo, (1998). "Good Information, Bad Advice", Forbes Global, (Internet) March 31.

Edwards, Sebastian (1989). "What Does the International Monetary Fund Really Do? Reply to Goldstein" Carnegie-Rochester Conference Series on Public Policy, 31 (autumn), pp. 77-82. 
Fischer, Stanley, (1998). "The Asian Crisis Countries and International System Improvements." Berlin 1998. New York: The Trilateral Commission, pp. 3-7.

James, Harold, (1996). International Monetary Cooperation Since Bretton Woods. Washington: International Monetary Fund.

Jenkins, Jr., Holman, W., (1998). "Russia a Deadbeat? Funny the Banks Never Mentioned It." The Wall Street Journal, (September 2), p. A19.

Keynes, John Maynard, (1923). A Tract on Monetary Reform. Volume 4 of The Collected Writings of John Maynard Keynes. London: Macmillan and St. Martin's Press for the Royal Economic Society, 1971.

Meltzer, Allan H., (1988). Keynes's Monetary Theory: A Different Interpretation. Cambridge: Cambridge University Press.

Meltzer, Allan H., (1995). Sustaining Safety and Soundness: Supervision, Regulation and Financial Reform. Washington: The World Bank.

Meltzer, Allan H., (1998a). "Asian Problems and the IMF" Joint Economic Committee (February 24). Reprinted, Cato Journal, 17 (winter), pp. 267-274.

Meltzer, Allan H., (1998b). "Financial Structure, Saving and Growth: Safety Nets, Regulation, and Risk Reduction in Global Financial Markets." Presented at First International Conference, Bank of Korea (June). 
Mikesell, Raymond F., (1998). "The Future of the Bretton Woods Institutions." Jobs and Capital, 7 (spring), pp. 27-33.

Presnell, L.S., (1997). "What Went Wrong? The Evolution of the IMF 19411961." Banco Nazionale del Lavoro Quarterly Review, 50 (June), pp. 213-37.

Rogoff, Kenneth S., (1998). "The Risks of Unilateral Exchange Rate Pegs." Presented at the First International Conference, Bank of Korea (June).

Sokolov, Venyamin, (1998). "The Virus in Russia", New York Times, (June 1). 